\section{Hormonal Control of Lipid Concentration in Rat Heart and Gastrocnemius}

Ix perfused rat heart and isolated rat diaphragm the rate of release and oxidation of fatty acids from muscle glyeerides is increased by alloxan-diabetes ${ }^{1}$. These changes in diabetes involve actions of growth hormone and corticosteroids in insulin-deficient rats becauso they are not seen in muscles of hypophysectomized diabetic rats unless the animals are treated with growth hormone and cortisol ${ }^{1}$. As part of an investigation of the mechanisms of these changes we have investigated the effects of diabetes, hypophysectomy and treatment with growth hormone and cortisol on the concentrations of glycerides and phospholipids in rat heart and gastrocnemius (the latter as a representative skeletal muscle). The methods and procedure were as follows.

Rat hearts wore perfused for 10 min with medium containing glucose $(5.5 \mathrm{mM})$ and insulin $(0.1 \mathrm{unit} / \mathrm{ml}$.), and the excised ventricles frozen with a tissue clamp and powdered in a percussion mortar ${ }^{2}$. Gastrocnemius muscle was frozen in acetone-solid carbon dioxide mixture and powdored after $10 \mathrm{~min}$ of hind-limb perfusion through the abdominal aorta with the foregoing medium containing glucose $(11 \mathrm{mM})$ but no insulin. These perfusions removo blood and blood lipids. Details of induction of alloxandiabetes and treatment with growth hormone and cortisol were as described elsewhere ${ }^{2}$. The frozen muscle powder was extracted with chloroform/methanol $(2: 1 \mathrm{v} / \mathrm{v})$ $(15-30 \mathrm{ml} / \mathrm{g})$ in a Potter homogenizer, allowed to stand at $0^{\circ}$ for $2 \mathrm{~h}$ and centrifuged. The supernatant was shaken with 0.3 vol. of $4 \mathrm{mM}$ magnesium chloride and phases separated by centrifugation after $30 \mathrm{~min}$. The chloroform phase was evaporated to dryness at $70^{\circ}$ and the residue taken up in about $7 \mathrm{ml}$. of chloroform and a sample $(0.5 \mathrm{ml}$.) taken for determination of phospholipid$\mathrm{P}$ (ref. 3), after evaporation of chloroform and oxidation with $0.15 \mathrm{ml}$. concentrated $\mathrm{H}_{2} \mathrm{SO}_{4} / \mathrm{HClO}_{4}(2: 1 \mathrm{v} / \mathrm{v})$. The remainder was shaken with $0.5 \mathrm{~g}$ silicic acid to remove phospholipid ${ }^{4}$ (confirmed by assay of phospholipid-P). A sample of supernatant $(4 \mathrm{ml}$.) was evaporated to dryness and glycerides separated by thin-layer chromatography on 'Silica Gel $G$ ' (Merck) using as solvent petroloum ether (fraction $40^{\circ}-60^{\circ}$ )/di-ethyl ether/methanol/acetic acid (90:20:2:3 v/v). As markers crude triolein (British Drug Houses, Ltd.) containing mono- and di-olein, and pure tripalmitin and mono-olein (Hormel Institute, University of Minnesota), were used (about $0.5 \mu$ mole). The $R_{F}$ values of the separated classes were: monoglycerides 0.05 ; diglycerides 0.45 ; triglycerides 0.90 . The spots, located by markers, were scraped from the plate and extracted twice with $2 \mathrm{ml}$. of chloroform/ mothanol $(2: 1 \mathrm{v} / \mathrm{v})$. The extract was evaporated to dryness at $70^{\circ}$, saponified with $0.5 \mathrm{ml} .4$ per cent potassium hydroxide in 95 per cont ethanol for $30 \mathrm{~min}$ at $60^{\circ}$, acidified with $0.5 \mathrm{ml} .10$ per cent $\mathrm{HClO}_{4}$, neutralized with saturated $\mathrm{KHCO}_{3}$, and $\mathrm{KClO}_{4}$ separated by centrifugation at $0^{\circ}$. Glycerol was assayed enzymatically in the supernatant ${ }^{5}$. Recoveries (using $1-\left[{ }^{14} \mathrm{C}\right]$-palmitate labelled tripalmitin from the Radiochemical Centre, Amersham, added to extracts of heart) were in excess of 90 per cent. Recovery of mono-olein was in excess of 80 per cent. Contamination with phospholipid-P was less than 0.05 per cent.

The results are shown in Table 1. In the glyceride series the concentration of triglyceride was greatly in excess of that of di- and mono-glyceride, the concentration ratios being $140: 1: 6$ in normal rat heart and $120: 1: 4$ in normal rat gastrocnemius. Theso values indicate that loss of the first fatty acid may limit triglyceride breakdown in muscle. The concentration of triglycoride in heart and gastrocnemius was significantly increased by alloxan-diabetes. In hypophysectomized rats alloxandiabetes failed to increase the triglyceride concentration unless the animals were treated with growth hormone
Table 1. Grychride and Phospholipin Coxcentrations IN Rat HiakT

\begin{tabular}{|c|c|c|c|c|c|}
\hline \multirow[b]{2}{*}{ Rat } & & \multicolumn{4}{|c|}{ 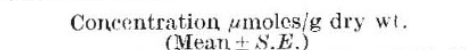 } \\
\hline & Tissue & $\begin{array}{l}\text { Trigly- } \\
\text { ceride }\end{array}$ & $\begin{array}{l}\text { Digly- } \\
\text { ceride }\end{array}$ & $\begin{array}{l}\text { Monogly- } \\
\text { ceride }\end{array}$ & $\begin{array}{l}\text { Phospholipiel } \\
\text { phosphorus }\end{array}$ \\
\hline Normal $(6)$ & Heart & * $13 \cdot 6 \pm 1 \cdot 4$ & $\begin{array}{l}0 \cdot 1 \\
0 \cdot 6\end{array}$ & $\begin{array}{l}0 \cdot 6 \\
0.7\end{array}$ & $\begin{array}{l}184+8 \\
163+8\end{array}$ \\
\hline Hypophysectomized (6) & & $10 \cdot 3 \pm 1 \cdot 3$ & 0.4 & 0.7 & $143 \pm 4$ \\
\hline $\begin{array}{l}\text { IIypophysectomized } \\
\text { diabetic }(6)\end{array}$ & & $10 \cdot 6+0 \cdot 9$ & $0 \cdot 3$ & 0.7 & $154 \pm 4$ \\
\hline $\begin{array}{l}\text { Hypophyscctomized } \\
\text { diabetic treated } \\
\text { growth hormone and }\end{array}$ & & & & & \\
\hline cortisol $(4)$ & & $* 22 \cdot 9 \pm 3 \cdot 7$ & - & - & $1+2 \pm 5$ \\
\hline Normal (8) & $\begin{array}{l}\text { Gastroc- } \\
\text { nemius }\end{array}$ & & $0 \cdot 1$ & $0 \cdot 4$ & $64 \pm 2$ \\
\hline Alloxan-diabetic (8) & & $26 \pm 2 \cdot 7$ & 0.4 & 0.5 & $63 \pm 1$ \\
\hline
\end{tabular}

and cortisol. The concentration of diglyceride (measured on pooled oxtracts) may also have beon increased in alloxan-diabetes whereas the concentrations of monoglyceride and phospholipids appeared to be unchanged. When hearts from normal rats were porfused for $60 \mathrm{~min}$. without substrate the triglyceride concentration fell from $18.7 \pm 0.8$ (8) to $8.7 \pm 0.7(8)$ (umoles/g dry wt.; mean $\pm S \cdot \bar{E}$. with number of hearts). No significant change in phospholipid was detected $(186 \pm 6-171 \pm 7)$.

These observations lead us to conclude that heart muscle triglycoride is broken down during perfusion, thus providing fatty acid for oxidation ${ }^{6}$. Evidence for the location of this glyceride in muscle cells has been presented ${ }^{1,7}$. The concentration of triglyceride, but not that of phospholipid, is increased by actions of growth hormone and cortisol in an insulin-deficient rat. Loss of the first fatty acid from triglyceride appears to limit breakdown in both normal and diabetic rats. The role of increased triglyceride concentration in accelerated lipolysis in diabetie muscle ${ }^{1}$ and the source of muscle glyceride (that is, whether derived from plasma glyceride or plasma not-esterified fatty acids) is under investigation.

We thank Mr. R. O. Law for help with perfusion of hind limbs and the British Diabetic Association, the Medical Research Council and the Royal Society for grants. R. M. Denton P. J. RANDIE.

Department of Biochemistry, University of Bristol.

${ }^{1}$ Garland, P. B., and Randle, P. J., Biochem. J., 93, 678 (1964).

${ }^{2}$ Newsholme, E. A., and Randle, P. J., Biochem. J., 93, 641 (1964).

${ }^{3}$ Lindberg, O., and Ernster, L., Meth. Biochem. Anal., 3, 1 (1956).

${ }^{4}$ Carlson, L. A., J. Atheroselerosis Res., 3, 334 (1963).

${ }^{5}$ Garland, P. B., and Randle, P. J., Nature, 196, 987 (1962).

6 Garland, P. B., Newsholme, E. A., and Randle, P. .., Biochem. J., 93, 665, (1964).

'Orth, D. N., and Morgan, H. E., J. Cell. Biol., 15, 509 (1962).

\section{Acrylamide-gel Electrophoresis of $\beta$-Lactoglobulins stored in Solutions at $\mathbf{p H} \mathbf{8 . 7}$}

Native $\beta$-lactoglobulins- $A$ and $-B$, mol. wt. 35,500 , can reversibly dissociate into sub-units of mol. wt. 17,750 in acidic ${ }^{1}$ or alkaline ${ }^{2}$ solutions. Aggregation of $\beta$-lactoglobulin- $A$ to a tetramer structure hes been observed ${ }^{1}$ in solutions of $p \mathrm{H} \quad 3 \cdot 5-5 \cdot 2$ stored at $4^{\circ} \mathrm{C}$. Trreversible denaturation of $\beta$-lactoglobulin occurs on heating ${ }^{3}$ neutral solutions above $65^{\circ} \mathrm{C}$ or on storage, ${ }^{4,5}$ in alkaline solution at $25^{\circ}$ (slowly in the $p \mathrm{H}$ range $8-9 \cdot 5$, more rapidly in solutions of higher $p \mathrm{H}$ ). This denaturation was shown by changes in iso-electric solubility, optical rotation and light scattering; Tiselius electrophoresis in 'Veronal' $(p \mathrm{H} \mathrm{8.4)}$ buffer separated one, or occasionally two, faster-migrating components in addition to native $\beta$-lactoglobulin. An initial reversible splitting followed by irreversible aggregation was postulated ${ }^{3}$, but the nature and number of products formed were not studied further. Bingham, Krugman and Estermann' recently noted that stored samples of $\beta$-lactoglobulin were separated by acrylamide disc electrophoresis? into five bands whereas the fresh material split into only two bands; they gave no indication 